\title{
Evaluation of Leadership Programs (PIM) Level III For Civil Servants In The Education and Training Center (Pusdiklat) of The Ministry of Manpower (Kemnaker) RI
}

\author{
Sudiharto \\ University State of Jakarta \\ Email: sudiharto_im12s3@mahasiswa.unj.ac.id \\ Dedi Purwana \\ University State of Jakarta \\ Email: dpurwana@unj.ac.id \\ Billy Tunas \\ University State of Jakarta \\ Email: tunas.billy@gmail.com
}

\begin{abstract}
The purpose of this study is to describe the implementation of Education and Training Leadership (Diklat PIM III) Level III for Civil Servants (PNS) in the Education and Training Center Ministry of Manpower (Pusdiklat Kemnaker RI) so that it can be used by policymakers to improve its implementation. The research method uses the program evaluation model CIPP (Context, Input, Process and Product) and Impact. Evaluation was carried out on the implementation of PIM III Training and Training held in the 2015-2016 period by the Pusdiklat Kemnaker RI. In this study involved 57 informants from the Ministry of Administrative and Bureaucratic Reform (PAN RB) as regulators, the Center for Training and Development of the State Administration Institution (P3D LAN) as a technical policy regulation, BNP2TKI (National Board for Placement and Protection of Indonesian Workers) as a place for alumni Diklat PIM III from Pusdiklat Kemnaker as the organizer. The validity of the instrument is carried out towards content, construction and language through expert consultations. Data is collected by considering triangulation, namely interviews, observations, document studies and expert opinions. Data analysis was performed based on themes or sub-focus and content on compliance with evaluation criteria. Overall the results of the evaluation research on the implementation of the Diklat PIM III Program by the Pusdiklat Kemnaker RI are considered lacking or $57.69 \%$ of the evaluation criteria can be met. Very Poor Achievement in the Impact (I) alumni sub-focus on the organization. The recommendation for regulators is the implementation of the Diklat PIM III Cycle Model as part of the Echelon III Position Selection with the central point of the Echelon III Structural Position Competence set by the measured and traceable PANRB to produce superior and competitive human resources personnel.
\end{abstract}

Keywords: Diklat PIM III, Evaluation, Context, Input, Process, Product and Impact 
Received: 20 September 2019;

Accepted: 28 November 2019;

Publish; December 2019.

\section{How to Cite:}

Sudiharto., Purwana, D., M.R, \& Tunas, B. (2019). Evaluation of Leadership Programs (PIM) Level III For Civil Servants In The Education and Training Center (Pusdiklat) of The Ministry of Manpower (Kemnaker) RI. International Journal of Human Capital Management, 3 (2), 70-90. https://doi.org/10.21009/IJHCM.03.02.07

\section{INTRODUCTION}

Coaching and developing civil servant (PNS) competencies can be carried out through Education and Training (Diklat), in the form of Position Training for Echelon III Officials namely PIM Tk. III. Regulation on the implementation of Program Diklat PIM IIIis carried out by the Ministry of Empowerment of State Apparatus and Bureaucratic Reforms (Kementerian $P A N R B$ ) and operational policies implemented by the State Administration Agency $(L A N)$, which is regulated in PerKaLAN Number 19 of 2015. Education Center and Training of the Indonesian Ministry of Manpower (Pusdiklat Kemnaker), as organizer of the PIM Tk. III for Echelon III Officers in the ward. The Ministry of Manpower and stakeholders such as the National Board For The Placement and Protection of Indonesian Migrant Workers (BNP2TKI) is a National Board that reports on the implementation of the program to the President through the Minister of Manpower of the Republic of Indonesia.

The results of a previous study at the Ministry of Manpower Training Center that in the implementation of Program Diklat PIM III has not been oriented towards meeting the target number participants become the formation of competent leadership qualities; not yet the whole thing is to prepare training facilities and infrastructure and facilities for group discussion, Program Diklat PIM III is still part of the training, teaching materials and the module have not been found in the library and the Ministry of Education and Training Center web site, standard competency of an Echelon III Officer who has been determined has not yet become an internal reference learning in the classroom, benchmarking and laboratory but it focuses on agenda.

The results of the preliminary study at BNP2TKI as one of its organizations alumni PIM III Training and Education Education and Training Center (Pusdiklat Kemnaker) 58 people $(80.56 \%)$ out of 72 Echelon III people, Echelon IV positions as many as 197 people and 113 people (57.36\%) alumni from the Pusdiklat Kemnaker. Public opinion on the performance of the institution BNP2TKI with an achievement of $54 \%$ or less, the recommendation of the results of the Puslitfo study as policy input only reached $44 \%$ or less, as well the ability to absorb the budget experiences a downward trend every year. The performance of this government agency is believed to be a product of performance Echelon III officials, where the program executes the echelon III order (Report Performance Accountability of Government Agencies / LAKIP in 2015, 2016 and 2017).

BNP2TKI budget performance in 2014-2016, the trend continues to decline and in 2017 and 2018 it increased (7.75\%) due to the Up Grading Skills Program organized by the Sub Directorate Competence Harmonization of Mapping and Quality Directorate of BNP2TKI. Budget performance that has this downward trend indicates an inability to plan the less careful, the inability to predict change and anticipation, do not understand the tasks and functions that must be carried out or overlap, and the inability to make changes i.e. prepare, place and protect formal sector migrant workers aims to improve the welfare and dignity of migrant workers in Indonesia and abroad.

While the previous study at the sending institution participants of Education and Training PIM III (Program Diklat PIM III), obtained information in the form of not yet preparing for the process selection in accordance with applicable regulations so that participants who are delegated will indeed be promoted; Program Diklat PIM III has not been 
a part of PNS career planning; and participants sent are still there to cover lack of participants. Observing this, it is necessary to find a solution so that the implementation of Program Diklat PIM III can be effective and efficient. Through The Evaluation Program Diklat PIM III can be used as an alternative solution.

The Diklat PIM III Program Evaluation Research is important for decision making for regulatory institutions, technical implementers and users in terms of the planning and implementation process and evaluating products and impacts that are appropriate to the institutional context. This agrees with the research of Tootian, S. (2019) that the context, input, process and product are interrelated. Gunung, Nyoman and IK Darma (2019), that the constraints on product components are closely related to context, input and process. Research Rehman, Zahra, Muazza Mahmood and Shamza (2018), that in the learning process that only focuses on learning theory and memorization will result in low product and impact on the organization. Research Mulyatiningsih (2016), suggests that in practice curriculum material is reproduced so that it can be applied to daily work, on the other hand there are participants who are still incompatible between positions with training material. Dina Amaluis Research (2015), using the Kirkpatrik evaluation model suggesting the need conduct training needs analysis so that the implementation of training programs can improve the competency of participants.

\section{A. Definitions}

\section{LITERATURE REVIEW}

\section{Evaluation}

Evaluation as a systematic process for determining or making a decision to what extent the teaching objectives have been achieved by students in the Grondlund's learning process in Purwanto (2006). According to Wringstone, the truth is an assessment of learning growth and progress toward inner goals and values curriculum that has been established and formulated by educational institutions concerned (Djaali and M. Pudji, 2008). Evaluation is a systematic process in the selection, collection, analysis and provision information carried out through measurement and assessment to make the right decision for a phenomenon, by comparing results or output with evaluation criteria, so that it can be determined that the object being evaluated is valuable or beneficial to the organization.

\section{Program}

The program can be called the realization of the policy (Suharsimi Arikunto \& Cepi Safruddin Abdul Jabbar, 2009). The program is a complex people, organizations, management, and resorts that collectively make up a continuing endeavor to reach some particular outcomes, in response to some perceived educational, social or commercial problems (Fitzpatrick, Jody L.; James R, Sanders; \& amp; Blaine R.Worthen, 2004).

\section{Program Evaluation}

Program evaluation is a process of providing information which can be used as a consideration to determine prices and services of the objectives to be achieved, design, implementation, and impact for help accountability and increase understanding of the phenomenon of a program (Widoyoko, 2016).

\section{B. Aims of Program Evaluation}

The purpose of program evaluation according to Mulyatiningsih (2011; 114-115) carried out with the aim to: show the contribution of the program towards the achievement of organizational goals. The main objectives of program evaluation according to Arikunto and Jabbar is an effort to find out the implementation level of a policy carefully by knowing the effectiveness of each component. The main purpose of program evaluation according to Talmage (Fitzpatrick. Et al. 2004; 11) are (1) To render judgments on the worth of the program, (2) To assist decision-makers responsible for deciding policy, (3) To serve a political function. 


\section{Program Evaluation Models}

The program evaluation model according to Kaufman and Thimas is a quote by Arikunto and Jabbar (2009), namely: a). Goal-Oriented Evaluation Model; b). developed by Tyler, Goal Free Evaluation, developed by Scriven; c). Formative Summative Evaluation Model, developed by Michael Scriven; d). Countenance Evaluation Model, developed by Stake; e). CSE-UCLA Evaluation Model, emphasizing on evaluation time done; f). Discrepancy Evaluation Model, developed by Provus; g). The Kirkpatrick Model, developed by Donald Kirkpatrick; h). CIPP Evaluation Model, developed by Stufflebeam.

In the evaluation of this program, the CIPP Model will be used which focuses on context, input, process, and products as well as Impacts alumni on organizational performance. Based on opinions, Nana Sudjana and Ibrahim (2004) each of these components mean the following:

a. Context: situations or backgrounds that affect educational goals types and strategies that will be developed in the system concerned, such as for example the problems with education felt, the state of the country's economy, people's outlook on life.

b. Inputs: facilities, materials and strategic plans that are set to achieve educational goals.

c. Process: implementation of strategies and use of facilities, capital, materials in real activities in the field.

d. Product: results achieved both during and at the end development of the relevant education system.

e. Impact: the impact of alumni on the performance of their organizations he led. In this study, PIM III alumni institutions were selected is BNP2TKI.

\section{Previous Research Studies}

Mulyaningsih (2016) analyzes evaluations implementation of education and training (training) resource competencies apparatus organized by BKD Magelang City. This research shows that the implementation of competency training has been running good and in accordance with the specified criteria although still available some obstacles.

The conclusion is that the implementation of the resource competency training apparatus organized by BKD Magelang City has been in accordance with aspects of education and training although still encountered few obstacles. In the curriculum aspect, the proportion between theoretical material and material practice to reproduce practice material so that training participants can apply in daily work. Aspects of participants, still there mismatch between the participants' daily work tasks and the material training that he followed.

\section{E. Evaluation Criteria}

Program evaluation is an attempt to find out the level implementation of a program or policy. So that the results are objective in evaluating the program, it is necessary to make a benchmark as standard in the form of evaluation criteria as a measure of success. Evaluation Criteria used as a benchmark to measure context, input, process, product, and impact. Further evaluation criteria can be examined in the results and discussion.

\section{METHODOLOGY}

\section{A. Research Objectives}

This study aims to describe the implementation of Level III Leadership Training (PIM) for Civil Servants (PNS) organized by the Education and Training Center of the Ministry of Manpower (Pusdiklat Kemnaker) so that it can be used by policy makers to improve their implementation. Specifically, the purpose of this study is to: 1). determine the goals, priorities, and objectives of the Leadership Training and Education Program (PIM) III organized by the Republic of Indonesia Education and Training Center. 2). Review availability resources, steps needed to achieve the goal and the objectives of the Leadership Training and Education Program (PIM) III held by the Education and Training Center of the Ministry of Manpower (Pusdiklat Kemnaker) which is held continuously. 3). Reviewing the implementation of the Leadership Training Program (PIM) III which organized by the 
Education and Training Center of the Ministry of Manpower (Pusdiklat Kemnaker). 4). Assessing success the implementation of the Leadership Training Program (PIM) III held by the Education and Training Center of the Ministry of Manpower (Pusdiklat Kemnaker).

\section{B. Place and Time of Research}

The place of this research has been conducted at the Education and Training Center of the Ministry of Manpower (Pusdiklat Kemnaker), BNP2TKI, LAN RI, and PAN RB. The research time in the first semester of 2018, with the main target in this study is Education and Training Leadership (PIM III) which was held in the 2015-2016 period.

\section{Research Approach, Method and Design \\ 1. Research Approach}

The approach used in this research is a qualitative approach to evaluative the research. Individuals involved play a role as research partners (co-researchers) and partner actors (cosubjects). As research partners, very useful for the process of idea creation, formulation and organizing research designs, and drawing conclusions experience-based. As a partner, the perpetrators are examined to participate in activities that are being researched (Norman K. \& amp; Lincoln, 2009). Researchers interact directly with the individual organizer's program, where the program is organized by the Education and Training Center of the Ministry of Manpower (Pusdiklat Kemnaker) and Training Center and in the PIM III Diklat alumni organization, BNP2TKI.

\section{Research Methods}

The method used is the evaluation research method, by measure the quality of the PIM III Training Program with the use of evaluation criteria as a measure of success as well involving the organization responsible for administration PIM III like PAN RB and LAN RI.

\section{Research Design}

The study design was designed by connecting between criteria evaluation in each aspect evaluated by the CIPP and Impact models. Basically, this evaluation research activity is an assessment effort for the performance of the PIM III Training Program as a regulatory product and legislation from PAN RB and LAN. For this, it is necessary to describe a research model design as follows. 


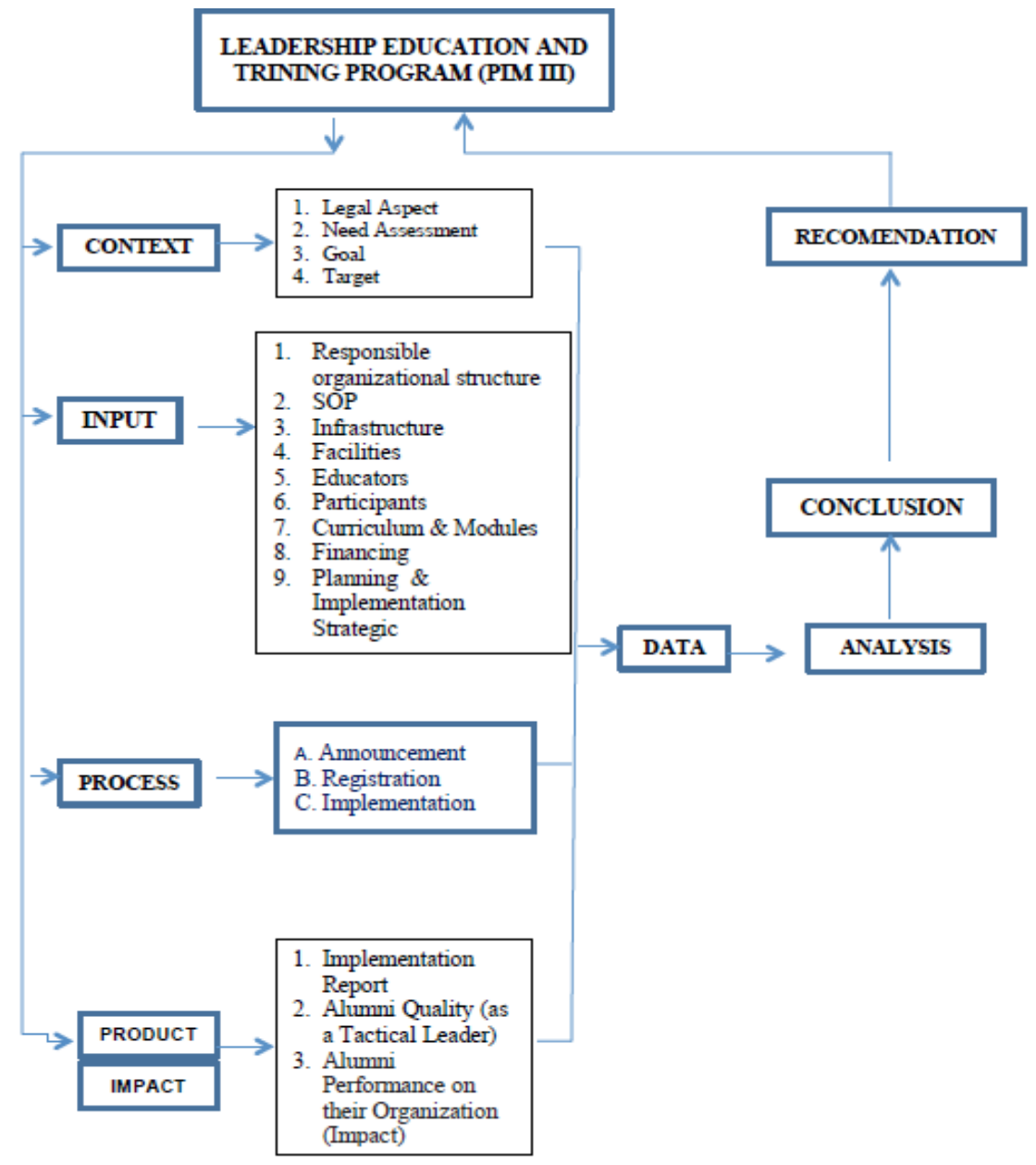

Figure 1. Design Research

\section{Research Instruments}

The instruments used for data collection are: Observation Guidelines and Interview Guidelines.

\section{E. Data Collection Techniques and Procedures \\ 1. Data Collection Techniques}

According to Emzir (2012) as for general data collection techniques used in this research are: Interviews, Observation and Study Document.

\section{Data Analysis Techniques}

The qualitative analysis technique used in this study is a model Miles and Huberman (1984). There are three types of activities in the analysis of qualitative data, namely: Data reduction, Data Model (Data Display) and Verification Conclusion.

\section{Withdrawal of Informants}

From all the results have been recorded in the field notes, then the researchers reduce the field notes by confirming the concepts found in the field through in-depth interviews or in-depth interviews with a number of selected informants.

Tabel 1. Matrix of Possible Choices Selected Informants 


\begin{tabular}{|c|c|c|}
\hline & & $(\mathrm{PAN}-\mathrm{RB})$ \\
\hline & & Head of the P3D LAN \\
\hline & 3. & Head of the Employment Bureau Kemnaker \\
\hline & 4. & Head of the Pusdiklat Kemnaker \\
\hline \multirow[t]{5}{*}{ INPUT } & 1. & Head of the Pusdiklat Kemnaker \\
\hline & 2. & Head of the organizing field \\
\hline & 3. & Head of Program \& Evaluation \\
\hline & 4. & Head of Administration \\
\hline & 5. & Educators \& Trainer (Widyaiswara) \\
\hline \multirow[t]{5}{*}{ PROCESS } & 1. & Head of the Pusdiklat Kemnaker \\
\hline & 2. & Head of the organizing field \\
\hline & 3. & Head of Program \& Evaluation \\
\hline & 4. & Head of Administration \\
\hline & 5. & Educators \& Trainer (Widyaiswara) \\
\hline \multirow[t]{4}{*}{ PRODUCT } & 1. & Head of the Pusdiklat Kemnaker \\
\hline & & Head of the organizing field \\
\hline & 3. & Head of Program \& Evaluation \\
\hline & & Alumni \\
\hline \multirow{3}{*}{$\begin{array}{l}\text { IMPACT on Alumni's } \\
\text { Organizatio }\end{array}$} & 1. & The Director \\
\hline & & The Same Level Mate \\
\hline & 3. & Sub-Ordinate \\
\hline
\end{tabular}

\section{RESULT AND DISCUSSION}

Evaluation of the PIM III Training Program at the Republic of Indonesia Ministry of Education and Training Center conducted March - July 2018 at the PIM III Education and Training Program PIM III which was held in the period of 2015 and 2016 in the Education and Training Center RI Ministry of Manpower. Informants in the evaluation totaled 57 informants from Kemenpan RB, LAN RI, Kemnaker RI (Pusdiklat Kemnaker, Bureau Organization and Staffing of the Ministry of Manpower, Research and Development Agency Ministry of Manpower), National Agency for Placement and Protection Indonesian Workers (BNP2TKI), and PIM III Training participants alumni. The informant is obtained based on the actor who represents the regulator, technical implementer or user. Informants also obtained by snowball sampling recommended by the informant beforehand. The characteristics of the informants in this study can be seen in more detail in the following table.

Tabel 2. The Characteristic of the Informants

\begin{tabular}{|c|c|c|c|c|c|c|c|c|c|c|c|c|c|c|c|}
\hline \multirow[b]{2}{*}{ No } & \multirow[b]{2}{*}{ Lokus } & \multicolumn{2}{|c|}{ Seks } & \multicolumn{3}{|c|}{ Usia } & \multicolumn{3}{|c|}{ Pendidikan } & \multicolumn{5}{|c|}{ Jabatan } & \multirow[t]{2}{*}{$\mathbf{E}$} \\
\hline & & L & P & $31-40$ & $41-50$ & $51-60$ & s-1 & s-2 & $5-3$ & wi & Es:2 & Est3 & Es: 4 & Staf & \\
\hline 1 & $\begin{array}{l}\text { Education } \\
\text { Training Center of } \\
\text { the Ministry of } \\
\text { Manpower } \\
\text { (Pusdiklat) } \\
\end{array}$ & 5 & 9 & 3 & 5 & 6 & 8 & 4 & 2 & 3 & 1 & 3 & 6 & 1 & 14 \\
\hline 2 & $\begin{array}{lr}\text { Ministry } & \text { of } \\
\text { Administrative \& } \\
\text { Bureaucratic Reform } \\
\text { (PAN RB) }\end{array}$ & 1 & - & - & $\cdot$ & 1 & $\cdot$ & 1 & $\cdot$ & - & - & 1 & - & - & 1 \\
\hline 3 & $\begin{array}{l}\text { State Administration } \\
\text { Institute (LAN RI) }\end{array}$ & 1 & 1 & - & 1 & 1 & - & 2 & - & - & 1 & 1 & - & - & 2 \\
\hline 4 & $\begin{array}{l}\text { An Organization for } \\
\text { Alumni : }\end{array}$ & -- & - & - & - & -- & - & -- & - & - & - & - & - & - & - \\
\hline A & Director & 4 & - & - & $\cdot$ & 4 & $\cdot$ & 3 & 1 & - & 4 & - & 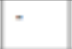 & - & 4 \\
\hline B & Alumni & 5 & 7 & $\cdot$ & 8 & 4 & 6 & 6 & - & - & $\cdot$ & 12 & - & $\cdot$ & 12 \\
\hline \multirow[t]{4}{*}{$\mathrm{C}$} & Sub-Ordinat & 10 & 14 & 4 & 11 & 9 & 15 & 9 & 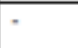 & - & - & - & 24 & - & 24 \\
\hline & Jumlah & 26 & 31 & 7 & 25 & 25 & 29 & 25 & 3 & 3 & 6 & 17 & 30 & 1 & \multirow[t]{2}{*}{-} \\
\hline & Prosentase & $\begin{array}{c}(45, \\
61 \\
\%) \\
\end{array}$ & \begin{tabular}{|c|c}
$(56$, \\
39 \\
$\%)$ \\
\end{tabular} & $\stackrel{(12,28}{\%}$ & $\begin{array}{c}(43,86 \\
\%)\end{array}$ & $\begin{array}{l}(43,86 \\
\%)\end{array}$ & $\begin{array}{r}(50, \\
88 \\
\%) \\
\end{array}$ & $\begin{array}{r}43, \\
86 \\
\%) \\
\end{array}$ & $\begin{array}{c}(5,26 \\
\%)\end{array}$ & $\begin{array}{c}(5,26 \\
\%)\end{array}$ & $\begin{array}{c}(10, \\
52 \\
\%)\end{array}$ & $\begin{array}{c}(29, \\
82 \\
\%)\end{array}$ & $\begin{array}{l}(52, \\
63 \\
\%) \\
\end{array}$ & $\begin{array}{c}(1,77 \\
\%)\end{array}$ & \\
\hline & Jumlah Total & \multicolumn{2}{|c|}{57} & \multicolumn{3}{|c|}{57} & \multicolumn{3}{|c|}{57} & \multicolumn{5}{|c|}{57} & 57 \\
\hline
\end{tabular}


Data collection method using in-depth interviews (in-depth interview), documentation study, observation and participatory observation by the researcher himself as a PIM III Training participant in 2017. Researchers' reason participatory observation is expected to obtain more data and information deep. Data collection instruments in the form of observation guidelines and interview guidelines.

Furthermore, the results of the evaluation and discussion of this study will be presented with reference to the focus, sub focus, evaluated aspects and criteria evaluation. Evaluation instruments were prepared based on the references above then described in accordance with the findings in the field, both obtained through interviews, documentation studies, and observations. Ignoring the criteria evaluation on each aspect evaluated is presented in the form of a percentage for each aspect that is evaluated then to sub-focus. To facilitate searching the results of the evaluation in more detail, the researchers made the master table first then details each sub-focus.

Based on the results of research that can be mapped the evaluation results the implementation of the PIM III Education and Training program with Spider Web about Evaluation Results of the PIM III Education and Training Program at the Indonesian Ministry of Education and Training Center, as shown below.

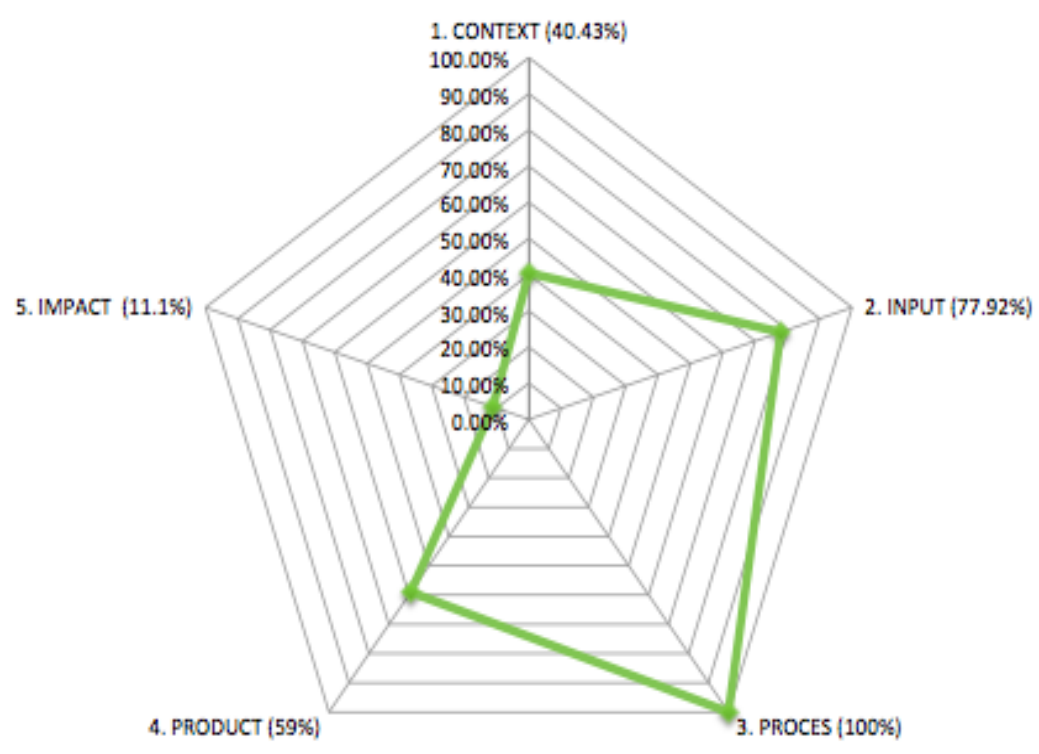

Figure 2. Spider Web about Evaluation Results of the PIM III Education and Training Program

Evaluation of the PIM III Training Program is a provisioning process information about achieving goals, designs or models, implementation of the organization and impact of graduates on their organization that can be made consideration of decision-makers. Information for retrieval decisions can be either terminated or resumed. So the point central evaluation is the availability of information to consider in decision making that has the right precision.

Similar with Stufflebeam and Shinkfield, J.S. Stark \& Thomas, Griffin \& Nix, Fitzpatrick etc, and Wholey that evaluation is a process systematic design in terms of selection, collection, analysis, and provision of information carried out through measurement and assessment as well compare the achievement of evaluation criteria with the results of the assessment and measurement so that the object being evaluated can be judged useful or valuable to the organization.

PIM III Training Program is a strategic education and training program that was initiated by the government in this case the policy by the Ministry of Utilization State Apparatus and Bureaucratic Reform (Kemenpan RB), technical policy by State Administrative Institutions and operational operations by the Pusdiklat in each ministry, one of which is the Indonesian Ministry of Education and Training Center. Observing this, the State considers that the PIM III Training Program has benefits and value for government 
organizations in terms of producing program leaders according to the tasks and functions of the organization.

Achievement of evaluation criteria in the PIM III Education and Training program as a whole the average lack of $57.69 \%$ of the achievement of the evaluation criteria. This matter means there is a gap of $42.31 \%$ or $42.31 \%$ of the evaluation criteria can't be fulfilled yet. Sequentially, the evaluation criteria are compared to those the largest to the smallest as follows: Subfocus The process of achieving very value good or $100 \%$, Input Subfocus achieved good value or $77.92 \%$, Subfocus The product reaches less value or $59 \%$, the Context Subfocus reaches the value very less or $40.43 \%$ and the impact on organizational performance reaches very poor value or $11.1 \%$. The most critical point of this PIM III Training Program is there in Context Subfocus, which can affect massively Subfocu next. In the Focus Subfocus, the first priority is on the assessment needs that will determine the goals and objectives of the program.

To achieve maximum success of about $91-100 \%$ evaluation criteria, it is necessary to make improvements to the focus according to priority by paying attention to aspects that are evaluated. More detailed discussion accordingly Subfocus is described in the following article.

\section{Context Subfocus}

Context Subfocus which consists of 4 aspects that are evaluated, namely the law foundation, need assessment, goals, and objectives to achieve compliance with average evaluation criteria are very less or around $40.43 \%$. Percentage of achievement to the evaluation criteria from the largest to the smallest, namely the legal basis achieve good value or $86.7 \%$ of the evaluation criteria, objectives reached a value of very less or by $50 \%$ of the evaluation criteria, need assessment reaches a value of very less or by $25 \%$ of the criteria the lowest evaluation and achievement in the target aspects achieved very poor value or by $0 \%$ against the evaluation criteria.

\subsection{Aspects Evaluated "Legal Basis" Achieve Good Value or $86.66 \%$ of the Evaluation Criteria.}

On the legal basis of the legal basis of the PIM III Training Center in the Education and Training Center The Indonesian Ministry of Manpower is: (1) Preamble of the 1945 Basic Law, paragraph 4; (2) PP 101 Year 2000 About Education and Training for Civil Servants' Position; (3) Head Regulation State Administration Agency Number 19 of 2015 concerning Guidelines Organization of Level III Leadership Education and Training; (4) Law No 15 of 2014 concerning ASN; (5) PP 11 of 2017 concerning Management Civil servants; (6) Regulation of the Minister of Administrative Reform and Reform Bureaucracy of the Republic of Indonesia. Act No. 38 of 2017 concerning Standards Competency Position of the State Civil Apparatus; (7) Ministerial Regulation Republic of Indonesia Employment Number 38 Year 2015 About Organization of Education and Training for Civil Servants Employment (8) Circular Number: 108 / K.1 / HKM.02.3 About Statement of Commitment to Implement Post-Training Change Projects; and (9) Procedure for Organizing Leadership and Technical Training, No. Doc: DSM / P / 10, No. Revisions: 05, Date Published: 9-12-2016. Of the 15 Evaluation Criteria about the legal basis, which have not been able to found is in the curriculum and modules used are not yet available appeal clause if the training participants are judged to have not passed or are not yet competent, and no modules that can be used.

\subsection{Aspects Evaluated Objectives achieve a value of Very Poor or $50 \%$ of the Evaluation Criteria.}

The purpose of the PIM III Training is to get a Structural Officer Echelon III as a Tactical Leader in a program in an organizational unit he led. Tactical leader in the program in the unit he dreams of having 8 evaluation criteria, namely: 1). graduated at a change project seminar plan, 2). graduated at the seminar on the report on the results of project changes, 3). attendance of at least $95 \%$ of total activities, 4). never get verbal or written reprimands from the host institution, 5). competent in the lead competency test, 6). competent in technical competency tests, 7). competent on competency test managerial, 8). Competent in the socio-cultural competency test. From the 8 results criteria, 4 pieces of yield criteria cannot 
be fulfilled namely numbers $5-8$, so they get designation Very Less or only reached $50 \%$ of the evaluation criteria.

Evaluation criteria that have not been fulfilled, are listed in the regulations and the applicable laws and regulations, including Law No. 19 of RI 2015 concerning Guidelines for Organizing PIM Training III. The four evaluation criteria it is written as a competency that a Structural Officer must possess Echelon III namely: lead competence, technical competence, competence managerial, and sociocultural competence. To assess the competency tests should be carried out, but never implemented competency tests are performed after following PIM III Training.

\subsection{Aspects Evaluated Need Assessment reaches a value of Very Less or $25 \%$ of the Evaluation Criteria.}

There are three evaluation criteria that need to be implemented achieved, namely need assessment conducted by involving stakeholders, the organizational structure that is responsible for conducting need assessments and document needs assessment activities. It is very necessary, bearing in mind the need assessment activities are the initial foundation before training well implemented. In line with the opinion of Kaswan (2011) that need assessment is the first step in training design, if it is not done well, regardless of the method or learning environment, training will not achieve the results or benefits expected by the organization.

\subsection{Aspects Evaluated Targets reach Very Poor values or 0\% of the Evaluation Criteria.}

Aspects Evaluated The objectives of conducting PIM III Training are increased competency as a Tactical leader in programs in institutions he leads. There are 4 evaluation criteria that are not fulfilled there are increased leadership competency, increased technical competence, increased managerial competence and increased social competence cultural. In accordance with the mandate of Law No. 15 of 2014 concerning ASN; PP 11 years 2017 About PNS Management; Perka LAN No. 19 of 2015 concerning Education and Training PIM III; and Regulation of the Minister of Administrative Reform and Reform Republic of Indonesia Bureaucracy Number 38 Year 2017 Concerning Standards State Civil Apparatus Competency Position, that the target of the Training is increased lead competency, increased technical competence, managerial competence and social-cultural competence. These four competencies never measured in the implementation of PIM III Training, well before implementation and completion. According to the CHR. Jimmy L. Gaol (2015), measurement of competence is an important series after it is present competency model.

\section{Input Subfocus}

Input Subfocus has 9 Evaluated Aspects, there are organizational structure, Standard Operating Procedures (SOP), infrastructure, facilities, training staff, participants, curriculum and modules as well as financing. Input sub-focus reached the whole of the criteria of evaluation of the average Good or of $77.92 \%$ of evaluation criteria. Achieving the largest percentage of evaluation criteria to the smallest namely Very Good organizational structure (100\%), Very Good planning and activity strategy (100\%), Very Good Infrastructure (92\%), Good trainer (85.7\%), Good financing (85.75), Good SOP (82.6\%), Less participants (60\%) and lowest curriculum and modules Very Less (40\%).

\subsection{Aspects Evaluated Organizational Structure achieves value Very good or $100 \%$ against evaluation criteria.}

Evaluated Aspects Organizational structure has 7 evaluation criteria, namely: 1) the element responsible; 2) elements that take care of administration, participants, facilities and infrastructure; 3) elements that take care of education personnel; 4) elements take care of monitoring and evaluation; 5) elements that take care of participants; 6) elements who take care of the infrastructure and; 7) elements that take care of infrastructure.

All evaluation criteria can be fulfilled. This organizational structure is what tasked with carrying out all procedures from beginning to end based on their respective duties and 
functions. This research found that aspect The evaluated organizational structure meets all the evaluation criteria stipulated by Shipping Number 19 of 2015.

This is consistent with research results from:

a. Tootian, S. (2019); The objective of this study was to examine the evaluation of training courses applied in succession planning in organizations using the CIPP model. This was an applied research in terms of purpose and descriptive-survey in terms of data gathering type. Statistical population of the study included 100 employees of Chamber of Commerce, of which a sample size of 80 people were selected using the random sampling method. The results revealed that context, input, output (product) and process components in the evaluation model of training courses used in succession planning are at a favorable level.

b. Gunung, Nyoman and IK Darma's research (2019); This study aimed at finding out the level of effectiveness of the implementation of teaching at PNB viewed from the relatedness of the components of 1) context; 2) input), 3) process, and 4) product. This study used the CIPP (Context, Input, Process, Product) model evaluation method. The data were collected using questionnaire, interview guide, and related documents. The subjects consisted of students, lecturers, and the management sfaff of departments in Politeknik Negeri Bali (PNB). The result of analysis showed that the effectiveness of the implementation of the teaching program at PNB viewed from the relatedness of context, input, process, and product falls into fairly effective category. While the obstacles in the implementation of the teaching programs at PNB include those in the components of context, input, process and product components. The outstanding obstacle occurs in the product variable.

Research from Lusiana (2017), on the Management of Diklat PIM IV in the Lubuk Linggau Training Center. The research method used is descriptive qualitative, with the results of the Diklat PIM IV in the institution implemented to build operational leadership competencies that will occupy echelon IV positions.

\subsection{Aspects Evaluated SOP reaches Good value or $82.6 \%$ against evaluation criteria.}

The aspect which was evaluated in the form of SOP of this program has fulfilled the criteria evaluation of SOP in accordance with Section No. 19 of 2015. Only it is still general. Therefore, the Republic of Indonesia Education and Training Center itself detailing the SOP by making a new SOP that is more detailed and specific. There are 4 SOPs, namely Leading Competency Test SOP, SOP Technical Competency Test, SOP Managerial Competency Test, and SOP Test Sociocultural Competence. The four SOPs are important and is the main objective of the competency improvement activities to be achieved from PIM III Training. So that in the future PIM III Training would be better, all four things it needs to be made in the form of a Competency Test SOP, so that the results you want achieved from increased lead, technical, managerial and competence sociocultural has a standard of evaluation and measurement that is traceable and measured.

\subsection{Aspects Evaluated Infrastructure reached Very Good or $92.3 \%$ of evaluation criteria}

Evaluated Aspects Infrastructure has 13 evaluation criteria, only 1 of which does not fulfill that is in terms of function and age such as the hall, class, and dormitory which is more than 20 years old, so it needs to be renovated. Infrastructure conditions which are available when going to the field indicates the need for renovations on a scale large enough.

The Education and Training Center of the Ministry of Manpower should conduct maintenance of the infrastructure. One of the maintenance of educational infrastructure aims to ensure the operational readiness of equipment to support the smooth work so that the optimal training results are obtained. In addition, maintenance of infrastructure good results rarely damage which means the cost of repairs can be suppressed to a minimum (Matin and Fuad, 2016). 


\subsection{Aspects Evaluated Facilities achieving Good value or $75 \%$ against evaluation criteria}

Evaluated Aspects Facilities have 4 evaluation criteria. Criteria which not met, namely reference books, modules or teaching materials about managing human resources and good leadership available in the library and can be accessed through the Education and Training Center of the Ministry of Manpower (Pusdiklat Kemnaker) and Pusdiklat website. Source this vital learning cannot be fulfilled by the Pusdiklat so that it can affect the precision of achieving goals and objectives. The Pusdiklat in the future implementation must comply with deficiencies in the Aspects Evaluated by Facilities material procurement. According to Benny A. Pribadi (2014), there are ways to fulfill these shortcomings, namely by producing their own training materials or buy the training material from another party.

\subsection{Aspects Evaluated Educator and Trainers (Widyaiswara) Achieve Good Grades or $85.7 \%$ of the evaluation criteria.}

Education staff does not meet the evaluation criteria in full, that is there are Widyaiswara Practitioners, Committees, Examiners, Guides and Counselors. Evaluation criteria that have not been met is the development of Widyaiswara's competence by LAN RI through the task line study. According to Sugandi (2016), Widyaiswara must be a learner throughout life that always adjusts skills and knowledge with a tendency that occurs in society. More specifically, the task of widyaiswara according to Misriadi (2016), is as a source learning, facilitator, manager, demonstrator, guide, motivator, and evaluator. Widyaiswara is a position that has a scope of duties, responsibility, authority and right to conduct educational teaching activities, training civil servants (Dikjartih PNS). Widyaiswara's task is not an easy task, they are required to continue to develop competencies in order to become good widyaiswara. It is unfortunate if the LAN as a responsible institution giving tasks to widyaiswara not giving activities competency development in the form of learning tasks.

\subsection{Aspects Evaluated Participants score less or $60 \%$ against evaluation criteria.}

Evaluated Aspects of Participants there are 5 evaluation criteria and those that have not fulfilled 1 namely participants from central, regional and various agencies department. Section 19 of 2015, requirements are stated PIM III Training participants, namely that "Participants from the province/district/ city follow the Education and Training outside the province of origin, so attach a Letter Information / Recommendation following the Education and Training from the Government Training Institute Province of origin accredited. " From these regulations that PIM III Training can accept participants in one batch consists of agencies from the Central, Regional and various departments. Diversity of the background of the participants, it is possible constructive communication across agencies on a CentralRegional scale. Forward, The Ministry of Manpower Education and Training Center needs to improve recruitment and selection so that PIM III Training to be better.

\subsection{Aspects Evaluated Curriculum and Modules achieve value Very less or $40 \%$ of the evaluation criteria}

The curriculum in this program is fulfilled 2 of 5 evaluation criteria. The three evaluation criteria that have not been met are: There is no assessment towards the eyes of the education and education program with the title of graduation; there is no reference book yet the main or modules as a minimum reading, and there is no bank case yet leadership and managerial. The assessment of the mastery of the material for each subject is sourced from the attendance and activeness of participants. Mastery of knowledge has not yet been measured. Mentor and evaluators who give values differ from each other because they have not there are standard standards that can be used to give an objective value in each eye training. In addition, there are no books or modules used during the training process. In fact, according to Hamid Hasan (2014), books or modules are an important component of a curriculum. 


\subsection{Aspects Evaluated in Planning and Strategy Activities reached Very good value or $100 \%$ against the evaluation criteria}

Evaluated aspects which are evaluated in the form of Planning and Strategy This program activity gets Very Good value because of all the criteria evaluation is fulfilled. The five evaluation criteria in preparation for implementation include: 1) there is the formation of an executive committee, recruitment of participants, recruitment of lecturers, accommodation and consumption preparation, scheduling, facilities and infrastructure, invitation list at the opening and closing events; 2) there is an evaluation plan for training staff, participants, and committees; 3) there is a strategy of activities in the classroom and outside the classroom; 4) there is a reporting plan accountability, and 5) there is a post monitoring and evaluation plan training.

\subsection{Evaluated Aspects Financing reaches Good value or 85.7 against evaluation criteria}

Evaluated Aspects Financing has not met the evaluation criteria as a whole. That is because in the study of documentation and participatory observation documents have not been found related to the scope of this program financing.

\section{Process Subfocus}

This program process sub-focus has 3 aspects that are evaluated, i.e. announcement, acceptance and implementation with each achievement $100 \%$ Overall evaluation is carried out on this sub-focus get very good results because it meets all the criteria evaluation.

\subsection{Aspects Evaluated Announcement achieves Very Good scores or $100 \%$ against evaluation criteria}

The aspect that has been evaluated in the form of an announcement on this program has been met the evaluation criteria. The entire scope of the evaluation criteria is in aspects. This announcement, namely: the time of implementation, the criteria and requirements of candidates participants, the deadline for submission of candidates is received by the Education and Training Center, announced on the website openly, and schedule activities. The latest data found to announce the PIM III Training Program in the form of a Circular of the Minister of Manpower of the Republic of Indonesia Number: Se.01 / Naker-SJ / Xii / 2017 Regarding Education and Training in the Field Ministry of Manpower and Capacity Building Employees Employment in 2018.

\subsection{Aspects Evaluated Acceptance achieves Very Good grades or $100 \%$ against evaluation criteria.}

Evaluated Aspects Admission to this program has also been fulfilled all evaluation criteria. There is an administrative Officer accepting participants, check administrative completeness, distributing participant's equipment (training kit), share rooms and orient room plans and order, acceptance of participants, as well as opening and orientation of the program, takes place with well. Even if there are deficiencies, especially in the participant selection phase, the implementation of PIM III Education and Training at the Republic of Indonesia Ministry of Education and Training Center can take place optimally. The structure that is responsible for implementation. PIM III Training is the Head of Education and Training Center, Head of Organization, Head of Subdivision Functional, head of education and training, widyaiswara, program and evaluation head, head of administration, and quality control. Sri Widoyo (interview, February 20, 2018).

\subsection{Aspects Evaluated Implementation achieves Very Good scores or $100 \%$ against evaluation criteria}

The Aspects Evaluated Implementation consists of Opening and program briefing; Learning activities on campus (Phase I - On Campus) - for 8 days; Project area approval activities change at each institution each (Phase II - Off-Campus or Taking Ownership) for 7 days; Activity campus learning and benchmarking (Phase III - On Campus) - for 18 day; Activity of implementing project plan changes to each institution each (Phase IV - OffCampus) - for 60 days; Closing and giving reward. 


\section{Product Focus}

Product subfocus consists of 3 aspects that are evaluated, namely the report implementation, alumni quality and impact on organizational performance after participants return to their home institution. Achieve fullness towards evaluation criteria average Less or $43.03 \%$. The biggest percentage achievement the evaluation criteria are reports with a Good value or $75 \%$ and the smallest the impact is Very Poor or $11.1 \%$, and the quality of the alumni is Very Poor or $43 \%$.

\subsection{Evaluated Aspects Reports reach Good or $75 \%$ against evaluation criteria}

The Aspects Evaluated in the form of Reports of this program have met the criteria evaluation of 3 of the 4 evaluation criteria. Evaluation criteria that have not been met are the report has no theoretical foundation. This aspect gets good grades or $75 \%$ evaluation criteria can be fulfilled. The theoretical foundation needs to be a part of making reports so that the report has a solid footing. Theoretical foundation that is not contained in the PIM III Training Program report is part of the scientific principles of an implementation report Training. According to Djuju Sudjana (2008), the Diklat report is a scientific work which should have a theoretical basis. The PIM III Training Report should contain an empirical study of primary and secondary data from Diklat activities PIM III is based on a theoretical study.

\subsection{Aspects Evaluated Alumni Quality reaches a Very value Less or $43 \%$ of the evaluation criteria}

The results of the qualitative evaluation that researchers conducted on the evaluated aspects of the Quality of PIM III Training Participants in Government Agencies where they served as echelon III officials found that PIM III alumni officials' competency characteristics as PIM III products such as which has been described above is generally not measurable. Accordingly qualitatively, the expected competency is realized in PIM III alumni it can indeed be felt by echelon II as a boss, colleague and level subordinate. However, the competency is not something that is obtained from PIM III brief training activities, but because of the character already attached to the personality of the alumni who work under his position, along also in the course of his life pursuing a career for decades as Government employees.

\section{Impact or Impact reaches a value of Very Less or $11 \%$ on evaluation criteria}

PIM III training is actually very good for selecting prospective officials structural echelon III because the program seeks to increase the capacity of Civil Servants as human capital. PIM III Training Pathway which implemented leading to efforts to increase: 1). Attitude and enthusiasm community service-oriented to the interests of the people, nation, and state homeland; 2). Technical, managerial, and / or leadership competence; 3). Efficiency, effectiveness, and quality of the tasks performed by the spirit of cooperation and responsibility in accordance with the work environment in the organization. The impact of graduates on organizational performance has never been evaluated so that the benchmarks of success at sending agencies as which is expected from the Program Diklat PIM IIIactivities has not been determined.

\section{Limitation}

This research has limitations, such as in interviews, document observation, and image capture. In general, among others, i.e. all informants are only willing to be interviewed individually, and not willing photographed for various reasons. Data collection permit, until writing this report is not willing to be issued, especially from PANRB.

In conducting interviews there are several limitations, namely (1) only willing to be interviewed by telephone; (2) the informant submits to subordinates but subordinates feel they do not have authority; and (3) the informant feels that he is not in his capacity because he has just been appointed a new position or hand it over to old officials who have moved institutions; (4) informant so busy that he is only willing to be interviewed individually; (5) limited time from researchers, related to the completion of studies. 
Efforts to quantify the qualitative research findings into the form of numbers is unusual. But researchers hope in research this can be objective so quantification is done through achieving percentages against evaluation criteria, even though researchers are aware of the measurement results through interviews cannot be equated with the results of measurements through observation or study documents.

\section{CONCLUSION \& RECOMMENDATION}

\section{A. Conclusion}

The conclusion of the PIM III Training Center for the Education and Training Center of the Republic of Indonesia Ministry of Manpower general achievement of success against evaluation criteria reaches a value less or $57.69 \%$, with the achievement of the assessment of the aspects evaluated as follows: 1). The aspects that are evaluated are highly rated good is the organizational structure that is responsible, the availability of infrastructure, announcement to prospective participants, acceptance of participants in the education and training center, implementation of activities according to the PIM III Training phase; 2). Aspects that are evaluated that received a good rating that is the legal basis, the availability of SOPs, the availability of facilities, education staff, planning and strategy activities, availability of costs and implementation reports; 3). Aspects that are evaluated only participants received less assessment; and 4). Aspects which is evaluated which gets a very poor evaluation, namely need assessment, goals, objectives, curriculum and modules, quality of training alumni and impact on performance alumni of the organization.

Based on each Subfocus CIPP and Impact method, the conclusion can be described below. Context Subfocus (C) achieves Very Poor value especially on achievement of aspects evaluated such as good legal foundation, need the assessment found no documents and no organizational structure responsible for the implementation of need assessment, goals are lacking because they were only able to meet some of the evaluation criteria, the targets were very lacking because it does not meet all the evaluation criteria. So the average percentage against the evaluation criteria obtained by $40.43 \%$.

Input Subfocus (I) achieves Good value because it fulfills aspects that are evaluated, include: a very good organizational structure responsible and infrastructure; good: SOP, facilities, education staff, and financing; those assessed as lacking in participant aspects; very lacking in aspects of the curriculum and module. So that the average percentage of the evaluation criteria obtained amounted to $77.92 \%$.

Process Subfocus $(\mathrm{P})$ achieves very good success because all the aspects evaluated are the announcement aspects, acceptance aspects and aspects implementation which includes: diagnosis of organizational needs, taking ownership, design changes and build teams, leadership, and laboratory evaluation. So that the average percentage of the evaluation criteria obtained by $100 \%$.

Product Subfocus $(\mathrm{P})$ achieves less success by reason of aspects that are evaluated: that achieves good value of the implementation report; that achieving very poor grades in the quality of training alumni and the impact of alumni performance towards the organization. The quality of alumni is very poor because there are 4 criteria evaluation that has not been done is the lead competency test, competency test technical, managerial competency test and sociocultural competency test. Criteria the evaluation that was fulfilled was the attitude assessment, the project plan evaluation change and assessment of project changes report. So the average percentage of the evaluation criteria obtained by $59 \%$.

Impact Subfocus or the impact of produced product, namely the impact of Alumni performance towards the organization they lead only meets the criteria. 'The development of the project implementation changes by superiors and training centers'. While the criteria that have not been met are: a). Assessment from the direct supervisor about: leadership, managerial, technical and competency enhancement sociocultural; b). Assessment of your fellow level colleagues with echelon III positions to the directorate regarding leadership competency improvement, managerial competence, technical and sociocultural; c). Assessment of subordinates with echelon IV positions to the directorate regarding leadership competency improvement, managerial competence, technical and sociocultural; d). The 
ability to carry out its duties and functions; e). The ability to absorb a budget to optimize its tasks and functions; f). The ability to make staff studies / studies as policy material; g). The ability to develop staff or subordinates; and h). Ability to delegate tasks to coworkers. So the average percentage of the evaluation criteria obtained was $11.1 \%$.

\section{B. Recommendation}

The recommendations of this study are:

1. For PAN RB, elaborating Leading Competencies, Technical Competencies, Managerial Competencies, and Sociocultural Competencies into Performance Criteria so that they can be more measured and traceable.

2. For LAN RI's Program Development and Training Center (P3D) in conducting a need assessment related to the needs of the PIM III Training Program for Echelon III Structural Officials and documenting the results. Implement the PIM III Training Model as part of the Echelon III Position Selection and not as part of coaching.

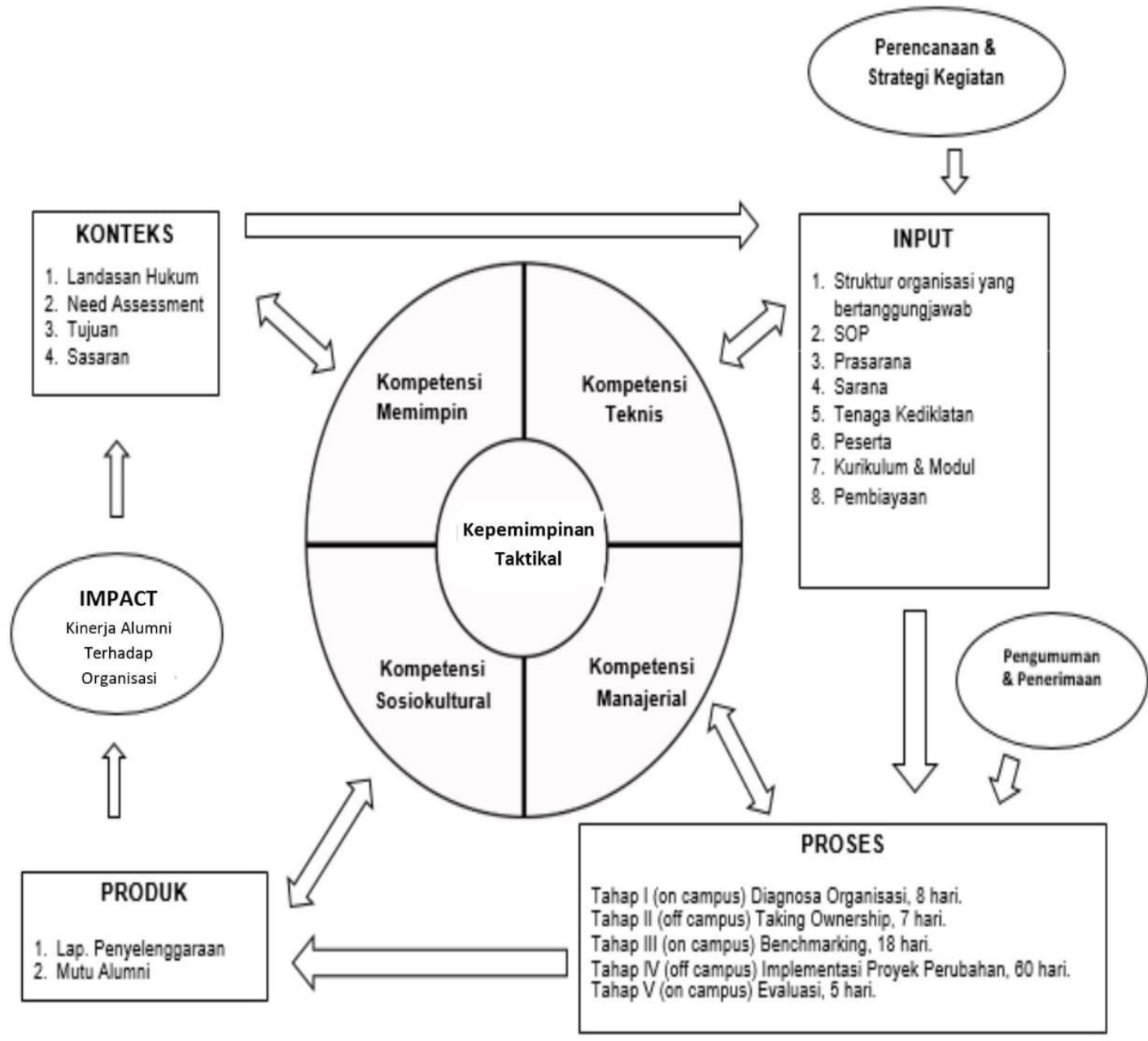

Figure 3 : Program Diklat PIM III Cycle Model As Part From the Echelon III Structural Position Selection

From Figure 3 of the Diklat PIM III Cycle Model III as Part of Selection above, can be explained as follows: the central point of program implementation Program Diklat PIM III contained in the middle circle in the form of Job Competence Echelon III Structural as Tactical Leader. A Tactical Leader has 4 competencies, namely: leadership competence, managerial competence, technical competence, and sociocultural competence. The four competencies as leaders. The tactical competencies leader an integral part of the sub-focus context, input, process, and product. The integral part referred to is an inseparable part of 
each sub-focus, so the Tactical Leader Competency becomes a benchmark success at each stage of the next sub-focus.

3. For the Education and Training Center of the Ministry of Manpower, to improve things that are lacking such as:

a. Availability of online learning materials, references related to leadership and managerial in the library, a collection of the latest leadership and managerial issues that come from print and electronic media.

b. Using competency standards set by PAN RB in designing classroom learning, benchmarking, designing change projects and final evaluation.

c. The final evaluation is carried out not only to assess the results of the project changes report but also to measure the achievement of the competencies of participants by conducting competency tests based on the competency standards of Echelon III Officers.

d. Propose a training budget comprehensively including evaluation of post-training.

4. For BNP2TKI to select prospective participants of the PIM III Training Program using guidelines published by LAN RI and evaluate the implementation of integrated change projects with employee performance appraisal using the 360-degree method.

\section{REFERENCES}

Abidin., Zainal. (2016). Evaluasi Pembelajaran: Prinsip, Teknik dan Prosedur. Bandung: Remaja Rosdakarya.

Afrizal. (2013). Metode Penelitian Kualitatif . Jakarta: Penerbit Rajawali Pers.

Amaluis., Dina. (2015). Analisis Efektifitas Program Pelatihan Diklat Pim Iii Terhadap Kompetensi Pejabat Eselon III Di Pemerintah Kabupaten Agam, ECONOMICA, Journal of Economic and Economic Education, Vol.3 No. 1.

Arifin., Zainal. (2011). Evaluasi Pembelajaran: Prinsip, Teknik, Prosedur. Bandung: PT Remaja Rosdakarya.

Arikunto, Suharsimi., \& Jabbar, Cepi Safruddin Abdul. (2009). Evaluasi Program Pendidikan: Pedoman Teoritis Praktis Bagi Mahasiswa \& Praktisi Pendidikan. Jakarta: Bumi Aksara.

Arthur, Ryan. (2018). Evaluasi Program Diklat Karya Tulis Ilmiah Untuk Widyaiswara Pusbangtendik Kemdikbud. Jurnal Penelitian dan Evaluasi Pendidikan, Vol. 22, No 1.

Aryanti, Teni., Supriyono, dan Ishaq, M.. (2015). Evaluasi Program Pendidikan Dan Pelatihan. Jurnal Pendidikan Nonformal. Vol. 10, No. 1.

Atmodiwirio., Soebagio. (1993). Manajemen Training: Pedoman Praktis bagi Penyelenggaraan Training. Jakarta: Balai Pustaka.

Aziz., Tengku Ariefanda. (2017). Pengaruh Rekrutmen \& Seleksi Terhadap Kinerja, Jurnal Aplikasi Bisnis Dan Manajemen, Vol. 3 No. 2.

Barob, Angela., \& Amstrong, Michael. (2012). Human Capital Management, Achieving Added Value Through People. Great Britain: Henry Ling Limited.

Beer., Michael. (2009). High Commitment High Performance: How to Build a Resilent Organization for Sustained Advantage. San Francisco: Josset-Bass A Wilet Imprint.

Briesch, Amy M. ., Ferguson, Tyler David., Daniels, Brian., Volpe, Robert J. ., Feinberg, Adam B. . (2017). School Psychology Review, Vol. 46 Issue 4 , Retrieved from http://web.b.ebscohost.com/ehost/pdfviewer/pdfviewer?vid=1\&sid=9c3f55c1-55794c17-9e3d-10769bff0752\%40sessionmgr104.

Czarnowski., Ireneusz. (2017). Learning from Examples with Data Reduction and Stacked Generalization, Journal of Intelligents \& Fuzzy Systems 32, Retrieved in http://web.b.ebscohost.com/ehost/pdfviewer/pdfviewer?vid=18\&sid=021f40e7-

97e7-43ac-b5b9-5f1676ed3598\%40sessionmgr101. 
Damayanti, Ayun Sri. (2016). Potret Perkembangan Inovasi Proyek Perubahan Alumni Diklat

Pim III Dan IV Di Kabupaten Mimika Papua Barat. Jurnal Administrasi Publik, Vol. XII, Nomor 2.

Danumiharja. (2014). Profesi Tenaga Kependidikan. Yogyakarta: Deepublish Publisher.

Daryanto, M. (1998). Administrasi Pendidikan. Jakarta: Rineka Cipta.

Denzin, Norman K., \& Lincolm, Yvonna Session. (2009). The Sage Handbook of Qualitative Research. California: Thousand Oaks.

Dewi., A.A. Inten Suastika. (2017). Proses Rekrutmen, Seleksi, Pelatihan, Penempatan Dan Kinerja Karyawan. Jurnal Manajemen dan Bisnis, Vol. 14 No. 1.

Dewi., Ketut Rina Purnami. (2017). Peran Human Capital Terhadap Efisiensi Perusahaan Perbankan Di Indonesia. Jurnal Sains dan Seni, Institut Teknologi Semarang, Vol. 6, No.1.

Djaali., \& Pudji, M. (2008). Pengukuran dalam Bidang Pendidikan. Jakarta: Grasindo.

Dorri, Safoura., Akbari, Malekeh., \& Sedeh, Mahmoud Dorri. (2016). Kirkpatrick Evaluation

Model for In-Service Training on Cardiopulmonary Resuscitation, Iranian Journal of

Nursing \& Midwifery Research Sep/Oct 2016 Vol. 21 Issue 5, Retrieved in http://web.a.ebscohost.com/ehost/pdfviewer/pdfviewer?vid=27\&sid=c67aa660cda4-46a4-a784-ad6cf5d29492\%40sessionmgr4010.

Ekawati., Ratna. (2017). Meningkatkan Kemampuan Inovasi Organisasi Melalui Human Capital. Jurnal INTEKNA, Vol. 17 No. 2.

Emzir. (2012). Metodologi Peneliian Kualitatif: Analisis Data. Jakarta: Rajawali Pers.

Escudero., Tomas. (2016). Evaluation Research in the 21st Century: A More and More Relevant Tool for The Educational and Social Development, Electronic Journal of Educational Research, Assessment \& Evaluation Vol. 22 Issue 1, Retrieved in http://web.a.ebscohost.com/ehost/pdfviewer/pdfviewer?vid=1\&sid=bbc73e2e-7e714035-ac29-cfd73645cf05\%40sessionmgr4007.

Farida, Ida. (2013). Rekrutmen, Seleksi, Pendidikan Dan Pelatihan Birokrat Perempuan Dalam Meningkatkan Pelayanan Publik Di Pemerintahan Kota Bandar Lampung. Jurnal Sosiohumaniora, Vol. 15 No. 1.

Fatima, Ghulam., Malik, Misbah., Abid, Uzma., \& Nayab, Dur-e. (2016). Early Childhood Special Education Program at the Outcome Phase: An Evaluation from Stake's Countenance Model Perspective. Bulletin of Education and Research Vol. 38 No. 2, Retrieved in http://web.a.ebscohost.com/ehost/pdfviewer/pdfviewer?vid=9\&sid=c67aa660-cda446a4-a784-ad6cf5d29492\%40sessionmgr4010.

Fitzpatrick, Jody L., Sanders, James R., Worthen, \& Blaine R. (2004). Program Evaluation Alternative Approaches and Practical Guidelines. New York: Longman Publishers.

Fuad, Nurhatti., \& Matin. (2016). Manajemen Sarana dan Prasarana Pendidikan. Jakarta: PT Rajagrafindo.

Gaol., CHR. Jimmy L. (2015). A-Z Human Capital Manajemen Sumber Daya Manusia: Konsep Teori, dan Pengembangan dalam Konteks Organisasi Publik dan Bisnis. Jakarta: Grasindo.

Gaol., Jimmy L. (2014). A to Z Human Capital. Jakarta: PT Gramedia Widia Sarana.

Geertz ., Clifford. (1981). Abangan, Santri, Priyayi dalam Masyarakat Jawa. Bandung: Dunia Pustaka Jaya.

Ghafari, Reza., Salmasi, Sousan Hassanzadeh., Golanbar, Parisa., Ranjbarzadeh, Fariba Salek., \& Saleh, Parviz. (2015). Evaluation of Educational Scholarship Festival Over the Past Seven Years from 2008-2014 in Iran Based on the CIPP Model. Research \& Develpoment in Medical Education 2015 Vol. 4 Issue 2, Retrieved in http://web.b.ebscohost.com/ehost/pdfviewer/pdfviewer?vid=1\&sid=af26ddf1-5c6c4833-b6f9-bb7787a59ea3\%40sessionmgr103.

Griffin, P., \& Nix P. (1991). Educational Assessment and Reporting. Sydney: Harcout Brace Javanovich Publisher.

H.D, Dewa Gede., Sappaile, Baso Intang., P, I Gusti Ngurah., Artaningsih, Luh., Sundayana, I Made., \& S., Gt. Ayu Dessy, An Evaluation of Instructional Process of Expert System Course Program by Using Mobile Technology-based CSE-UCLA Model. 
International Journal of Interactive Mobile Technologies, Vol. 11 Issue 6, , Retrieved http://web.a.ebscohost.com/ehost/pdfviewer/pdfviewer?vid=1\&sid=437da260-bba644f3-9886-ce9fc5a3ef7b\%40sessionmgr4008 (Accessed at January 16, 2018).

Hamalik, Oemar. (2005). Kurikulum dan Pembelajaran. Jakarta: Bumi Aksara.

Hamzah. (2017). Kompetensi Widyaiswara Dan Kualitas Diklat. Pembelajar: Jurnal Ilmu Pendidikan, Keguruan, dan Pembelajaran, Vol. 1 No. 2.

Hasan., Hamid. (2014). Evaluasi Kurikulum. Bandung: Rosdakarya.

Hasan., M. Iqbal. (2002). Pokok-pokok Materi Metodologi Penelitian dan Aplikasinya. Bogor: Ghalia Indonesia.

Hasibuan, Malayu P. (2007). Manajemen Sumber Daya Manusia. Jakarta: Bumi Aksara.

Hesselbein, Frances., \& Johnston, Rob (editor)., Sihadrini, Natalia Ruth (terj.). (2005). On Mission and Leadership, Misi dan Kepemimpinan. Jakarta: PT Elex Media Komputindo.

Irawan., Prasetya. (1999). Logika dan Prosedur Penelitian. Jakarta: STIA-LAN Press.

Jones ., Charles O. (1994). Pengantar Kebijakan Publik. Jakarta: Rajawali Press.

Kamil, Mustofa. (2003). Model-Model Pelatihan. Bandung: Universitas Pendidikan Indonesia.

Karding., A.K. (2008). Evaluasi pelaksanaan Program Bantuan Operasional Sekolah (BOS) Sekolah Menengah Pertama Negeri di Kota Semarang. (Tesis), Universitas Diponegoro, Semarang.

Kaswan. (2011). Pelatihan dan Pengembangan untuk Meningkatkan Kinerja SDM. Bandung: Alfabeta.

Kernodle, Micheal W., Rabinowitz, Erik., \& McKethan, Robert N. (2010). Peer Review: The Change from Formative to Summative Evaluation, Appalachian State University, Chronicle of Kinesiology \& Physical Education in Higher Education, Vol. 21 Issue 3 , Retrieved

in http://web.a.ebscohost.com/ehost/pdfviewer/pdfviewer?vid=1\&sid=bbd409b4-401b435d-86b1-e1740dbd7c57\%40sessionmgr4010.

Kozleski., Elizabeth B. (2017). The Uses of Qualitative Research: Powerful Methods to Inform Evidence-Based Practice in Education. Research \& Practice for Persons with Sever Disabilities, Vol. 42 Issue 1, Retrieved in http://web.a.ebscohost.com/ehost/pdfviewer/pdfviewer?vid=1\&sid=76c8083f-7db54da2-a8d0-c6871df866e1\%40sessionmgr4010.

Kum., Thamrin A. (2018). Model Evaluasi Reaction Level dari Kickpatrick Penyelenggaraan Pendidikan dan Pelatihan Kepemimpinan Tingkat III Angkatan II Provinsi Gorontalo. Jurnal Ilmu Administrasi, Vol. 7 No. 1.

Ljungberg, Anna Klarare., Fossum, Bjoorn., Furst, Carl John., \& Hagelin, Carina Lundh. (2015). Translation and Cultural Adaptation of Research Instruments-Guidelines and Challenges: An Example in FAMCAE-2 for Use in Sweden. Informatics for Health \& Social Care, Vol. 40 Issue 1, Retrieved from http://web.b.ebscohost.com/ehost/pdfviewer/pdfviewer?vid=1\&sid=b35c0f9b-cc124a24-87b4-34f3a2eaf7b1\%40pdc-v-sessmgr01.

Louch, Gemma., O'hara, Jane., \& Mohammed, Mohammed. (2017). A Qualitative Formative Evaluation of a Patient-Centred Patient Safety Intervention Delivered in Collaboration with Hospital Volunteers. Health Expectations, Vol. 20 Issue 5 , Retrieved in http://web.b.ebscohost.com/ehost/pdfviewer/pdfviewer?vid=1\&sid=3e4c3fba-687642f7-b105-a803f6abd2ff\%40sessionmgr104.

Lusiana. (2017). Pengelolaan Diklatpim Tingkat IV Pada Badan Pendidikan Dan Pelatihan Kota Lubuklinggau. Jurnal Manajer Pendidikan. Vol. 11 No. 4.

Miles, Matthew B., \& Huberman, A. Michael. (1984) Qualitative Data Analysis : A Sourcebook of New Methods. London: Sage Publication,1984.

Mulyaningsih. (2016). Evaluasi Pelaksanaan Pendidikan Dan Pelatihan Kompetensi Sumber Daya Aparatur Studi Di Badan Kepegawaian Daerah Kota Magelang. Jurnal Administrative Reform, Vol. 4 No. 4. 
Mulyatiningsih., Endang. (2012). Metode Penelitian Terapan Bidang Pendidikan. Jakarta: Alfabeta.

Musriadi. (2016). Profesi Kependidikan Secara Teoritis dan Aplikatif: Panduan Praktis bagi Pendidik dan Calon Pendidik. Sleman: Deepublish.

Nawawi, Hadari. (2005). Manajemen Stratejik Organisasi Non Profit Bidang Pemerintahan. Yogyakarta: Gadjah Mada University Press.

Nicholas., David. (1997). The Information Needs Interview: A Long Way from Library-Use Statics. Education for Information, Vol. 15 Issue 4, Retrieved in http://web.b.ebscohost.com/ehost/detail/detail?vid=14\&sid=021f40e7-97e7-43acb5b9-

5f1676ed3598\%40sessionmgr101\&bdata=JnNpdGU9ZWhvc3QtbG12ZQ\%3d\%3d\# $\mathrm{AN}=203447 \& \mathrm{db}=$ iih.

Noe, Raymod A. (2008). Employee training and Development. New York: Mc Graw Hill.

Nugraha., Nanang. (2018). Implementasi Pasca Diklat Kepemimpinan Tingkat III (Pola Baru) Dalam Rangka Peningkatan Kinerja Alumni Peserta Diklat Di Lingkungan Pemerintah Daerah Kabupaten Purwakarta. Jurnal Kediklatan, Pusat Pengembanan Sumber Daya Manusia Regional. Bandung: PPSDM Kemendagri.

Nugraha., Prayedi Cahya. (2018). Pengaruh Human Capital Terhadap Kinerja Perusahaan. Jurnal Administrasi Bisnis, Vol. 57 No. 2.

Nurkholis. (2003). Manajemen Berbasis Sekolah. Jakarta: Grassindo.

Pribadi., Benny A. (2014). Desain dan Pengembangan Program Pelatihan Berbasis Kompetensi: Implementasi Model Addie. Jakarta: Kencana.

Purwanto., Djoko. (2006). Komunikasi Bisnis. Jakarta: Erlangga.

Purwanto., Ngalim. (2013). Prinsip-Prinsip dan Teknik Evaluasi Pengajaran. Bandung: 2013.

Rachmawati, Tutik., \& Junio, Laurel Laras. (TT). A Study of Program Evaluation: Community of Information Group-A Triangle of Information, Government and Community. International Journal of Administration Science \& Organization, Vol. 22 No. 33, Retrieved in https://search.proquest.com/docview/1845146485/fulltextPDF/E5A4E0D3A6374AA 9PQ/1 ?accountid=32819.

Rachmawaty., Ike Kusnia. (2010). Manajemen Sumber Daya Manusia. Yogyakarta: Andi.

Rae., Leslie (terj). (2005). Using Evaluation in Training and Development. Jakarta: PT Buana Ilmu Populer.

Rakhmawanto., Ajib. (2006). Dampak Netralitas Terhadap Kinerja Pegawai Negeri Sipil (PNS). Jakarta: Pusat Penelitian dan Pengembangan Badan Kepegawaian Negara.

Rivai., Veithzal. (2004). Manajemen Sumber Daya Manusia Untuk Perusahaan. Jakarta: RajaGrafindo.

Roberts, Albert R., \& Gilbert, J. Greene. (2009). Buku Pintar Pekerja Sosial: Social Workers' Desk Reference. Jakarta: Gunung Mulia.

Sari., Kencana. (2017). Evaluation Of Education Implementation Of Training Pim Iii In Agency Of Human Resource Development, International Journal of Human Capital Management, Vol. 1 (2).

Smaldino, S. E. Russel. J.D. Heinich. R,. \& Molenda, M. (2007). Instructional Technology and Media for Learning. New Jersey: Pearson Merril- Prentice Hall Inc.

Stark, J.S., \& Thomas, A. (1994). Assessment and Program Evaluation, Simon \& Schuster. Needham Heights: Custom Publishing.

Stephen., Robbins. (2001). Perilaku Organisasi. Jakarta: Prenhalindo.

Stufflebeam, Daniel L., \& Shinkfield, Anthony J. (1985). Systematic Evaluation. Leiden: Kluwer Nijhof Publishing.

Stufflebeam, Daniel L., \& Shinkfield, Anthony J. (2007). Evaluation Theory, Model, and Application. San Fransisco: Willey.

Sudijono., Anas. (1996). Pengantar Evaluasi Pendidikan. Jakarta: Raja Grafindo.

Sudjana, Nana., \& Ibrahim. (2004). Penelitian Dan Penilaian Pendidikan. Bandung: Sinar Baru Algensindo.

Sudjana., Djudju. (2008). Evaluasi Program Pendidikan Luar Sekolah: Untuk Pendidikan Nonformal dan Pengembangan Sumber Daya Manusia. Bandung: PT Rosdakarya. 
Sugandi. (2016). Selayang Pandang Profesi Widyaiswara, Sekilas Pengalaman dan Perjalanan Seorang Widyaiswara. Yogyakarta: Garudhawaca.

Sugiyono. (2002). Metode Penelitian Administrasi. Bandung: Alfabeta.

Sugiyono. (2007). Metode Penelitian Kuantitatif Kualitatif dan R \& D. Bandung: Alfabeta.

Sukardi. (2015). Evaluasi Pendidikan: Prinsip \& Operasionalnya. Jakarta: Bumi Aksara.

Sulistiyani., Ambar Teguh. (2011). Memahami Good Governance: Dalam Perspektif Sumber Daya Manusia. Yogyakarta: Gava Media.

Sumanti., Rati. Kajian Evaluasi Pasca Diklat Kepemimpinan Tingkat II, III Dan IV. Aceh: Pusat Kajian Pendidikan \& Pelatihan Aparatur IV Lembaga Administrasi Negara Aceh Besar.

Sunyoto, Danang. (2012). Sumber Daya Manusia: Praktik Penelitian. Yogyakarta: CAPS Publishing.

Suryanto., Adi. (2018). Strategi Peningkatan Efektifitas Pelatihan Kepemimpinan: Telaah Teoretis Dan Empiris. Jurnal Borneo Administrator, Vol. 14 No. 1.

Swansburg., Russel C. (1995). Pengembangan Staf Keperawatan: Suatu Komponen Pengembangan. Boston: Jones \& Bartlett Publisher.

Syah., Muhibbin. Psikologi Pendidikan Dengan Pendekatan Baru. Bandung: PT Remaja Rosdakarya.

Tayibnapis., Farida Yusuf. (2008). Evaluasi Program dan Instrumen Evaluasi untuk Program Pendidikan dan Penelitian. Jakarta: Rineka Cipta.

Thaha., Rasyid. (2015). Efektivitas Implementasi Diklat Kepemimpinan Pola Baru Pada Pusat Pendidikan \& Pelatihan Kementrian Dalam Negeri Indonesia Regional Makassar. Jurnal Administrasi Publik, Vol. XI No. 1.

Tjiharjadi, Semuil, et. al. (2012). To Be a Great Effective Leader., Edisi-20. Yogyakarta: Andi.

Werner, J.M., \& DeSimone, Randy L. (2006). Human Resource Development (United States of America: Thomson.

Wholey, Joseph S., Hatry, Harry P., \& Newcomer, Kathryn E. (2010). Hand book of Practical Program Evaluation, Third Edition. San Francisco: Jossey-Bass.

Widoyoko, Eko Putro. (2016). Evaluasi Program Pembelajaran, Panduan Praktis bagi Pendidik dan Calon Pendidik. Yogyakarta, Pustaka Pelajar.

Woelders, Susan., \& Abma, Tineke. (2015). A Different Light on Normalization: Critical Theory and Responsive Evaluation Studying Social Justice in Participation Practices, New Directions for Evaluation; Summber Vol. 2015 Issue 146, Retrieved in http://web.a.ebscohost.com/ehost/pdfviewer/pdfviewer?vid=1\&sid=922d115d-ead14b35-8f96-1dbf9bf85b3e\%40sessionmgr4006.

Youker, Brandon W., Zielinski, Alayna., Hunter, Ouen C., \& Bayer, Nicholas. (2016). Who Need Goals? A Case Study of Goal-Free Evaluation. Journal of Multi Disciplinary Evaluation, Vol. 12 Issue 27, Retrieved in http://web.a.ebscohost.com/ehost/pdfviewer/pdfviewer?vid=16\&sid=78fd773082e3-4421-a24d-1111dfa18348\%40sessionmgr4008.

Yukl., Gary. (2004). Leadership in Organizations, 6th Edition. New York: Pearson Internasional Edition. 